\title{
Thermal Insulation and Strength Characteristics of Refractory Incorporating Natural Silica
}

\author{
Weerapol Namboonruang \\ Department of Civil Technology and Architecture, Faculty of Science and Technology, Muban \\ Chombueng Rajabhat University, MCRU 70150, Thailand
}

\begin{abstract}
This work emphasizes on the studying of using silica to develop for the production of refractory materials. Materials are tested at the cured times of 7,14 and 28 days. Results show that the cold crushing strength, flexural strength and bulk density increase with increasing cured times. On the other hand, the permanent linear change (PLC) decreases with increasing cured times. It is also found that adding more silica contents can increase the durability of cracking property due to temperature changing. This study concludes that the silica refractory materials (SRM) shows the enough quality to produce as the refractory material, type of the Conventional Cast/Pound $\left(815^{\circ} \mathrm{C}\right)$ for the agroindustry using the thermal energy of Thailand.
\end{abstract}

\section{Introduction}

The local agro-industry is one of industrial types which using thermal energy is the main energy to produce the products as well as the large industry. Some parts of the lining production are facing with continuous heat such as kiln using in the earthenware and ceramic industries, Incinerator using in the dried agro-product factory. These factories need to use the quality refractory materials and also be appropriate with the temperature using in each factory. Moreover, other materials such as: shale using as coarse aggregates to produce the refractory materials[1], slag which can reduce the size changing due to temperature[2], are also developed to use as raw materials. This work focuses on the use of silica which is cheap and easily finding in the local area, including considered as the inert materials to develop the production of refractory materials for the local agro-industry of Thailand.

\footnotetext{
*Corresponding author:bannork_civil@hotmail.com
} 


\section{Methodology}

\subsection{Manuscript Preparation}

The refractory powder Gunning castable grade is used to study the properties of SRM. The No. 8 sieves are used to percolate silica, then mixed with the refractory powder at $15 \%$ by weight. This composition is injected to the iron stack part of the agro- industry using thermal energy which the investment values are not over 10 Million USD. The plasticity property of SRM is tested by using "Ball in hand" $[3,7]$ method. The example materials are selected and tested at the cured times of 7, 14 and 28 days. For testing the thermal property, the materials are tested the drying at temperature of $110{ }^{\circ} \mathrm{C}$ for 24 hours and the fire at temperature of $815{ }^{\circ} \mathrm{C}$ for 5 hours. The total curing and dryout time are totally 49 hours, according to the testing furnace with thermostat manufacture-Serial No. SP08012990080, Capacity of $1,200^{\circ} \mathrm{C}$, ASTM C113-02[4]. For the mechanical properties, the cold crushing and the flexural strength are measured, according to ASTM C133-97[5], (CCS \& FS on the measurement of testing of digimatic caliper, Serial No. MW072967), Bulk density ASTM C134-95[6] and Permanence Linear Change[4].

\section{Results and Discussions}

\subsection{Mechanical and Chemical Properties}

The thermal energy property of SRM is observed at temperature of $815^{\circ} \mathrm{C}$ as shown in Figure 1. Results show that at cured times of 7, 14, 28 days, the cracked area due to the temperature changing cannot be found. This might be due to the SRM consists of silica contents which present the significant property in terms of shrinkage and swelling resistances due to temperature changing. The cold crushing strength (CSS) is also investigated and result shows that CSS increases with increasing cured times. This might explain due to the development of chemical reaction contained in SRM such as $\mathrm{CaO}, \mathrm{SiO}_{2}$ and $\mathrm{Al}_{2} \mathrm{O}_{3}$. At 7, 14 and 28 days, CSS values are 20.50, 22.70, and $28.25 \mathrm{Kg}_{\mathrm{cm}}{ }^{-2}$, respectively. Therefore, an internal stress field can modify the microstructural state of the material and thus can also strongly affect its mechanical behaviour[8,9]. As presented in several recent works dealing with the mechanical behaviour of such material[10,11,12,13]. According to the standard the cold crushing strength, (CCS) gunned type, the values are between 28.00 to $55.00 \mathrm{Kg} \cdot \mathrm{cm}^{-2}$ [5], then it can conclude that the cold crushing strength (CSS) of SRM passes the limited standard. Agreement with CSS, the flexural strength values increase with cured time. The maximum value is $4.53 \mathrm{Kg} . \mathrm{cm}^{-2}$ at cured time of 28 days as shown in Figure 2. However, according to the standard [5], it appears that the value is still lower than the standard which must not be less than $9.00 \mathrm{Kg} . \mathrm{cm}^{-2}$. 
Table 1. The Chemical Property Of Gunning Castable Refractory

\begin{tabular}{|l|c|}
\hline Chemical analysis: approximate (calcined basis) & Concentration, (\%) \\
\hline Silica $\left(\mathrm{SiO}_{2}\right)$ & 53.10 \\
\hline Alumina $\left(\mathrm{Al}_{2} \mathrm{O}_{3}\right)$ & 34.50 \\
\hline Iron $\left(\mathrm{Fe}_{2} \mathrm{O}_{3}\right)$ & 0.60 \\
\hline Titanium $\left(\mathrm{TiO}_{2}\right)$ & 0.70 \\
\hline Lime $(\mathrm{CaO})$ & 9.00 \\
\hline Magnesium $(\mathrm{MgO})$ & 0.30 \\
\hline
\end{tabular}

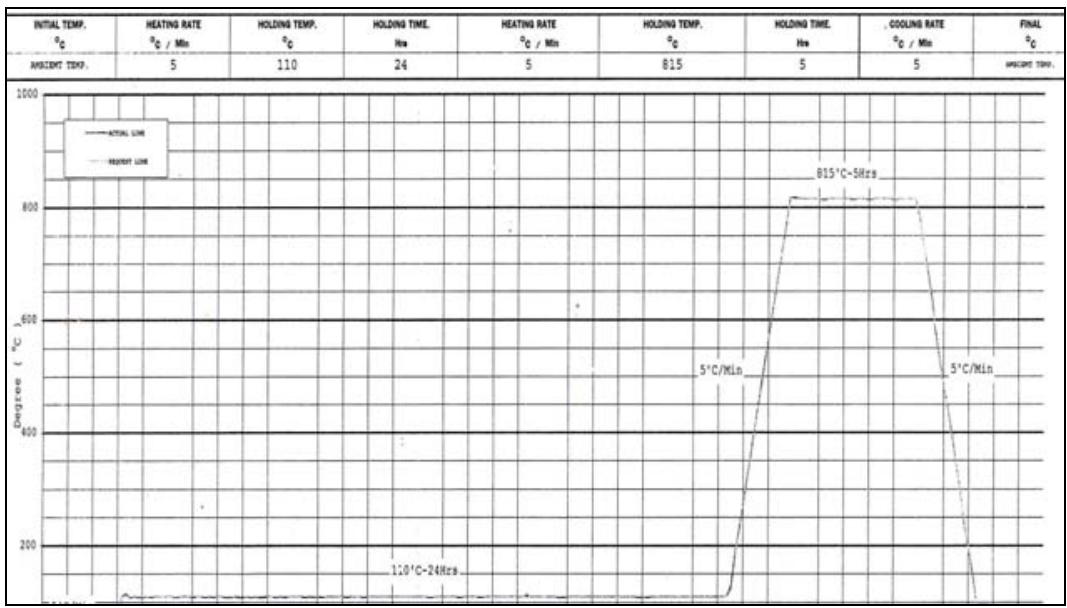

Figure 1. Show the lining schedule on total curing and dryout times of SRM

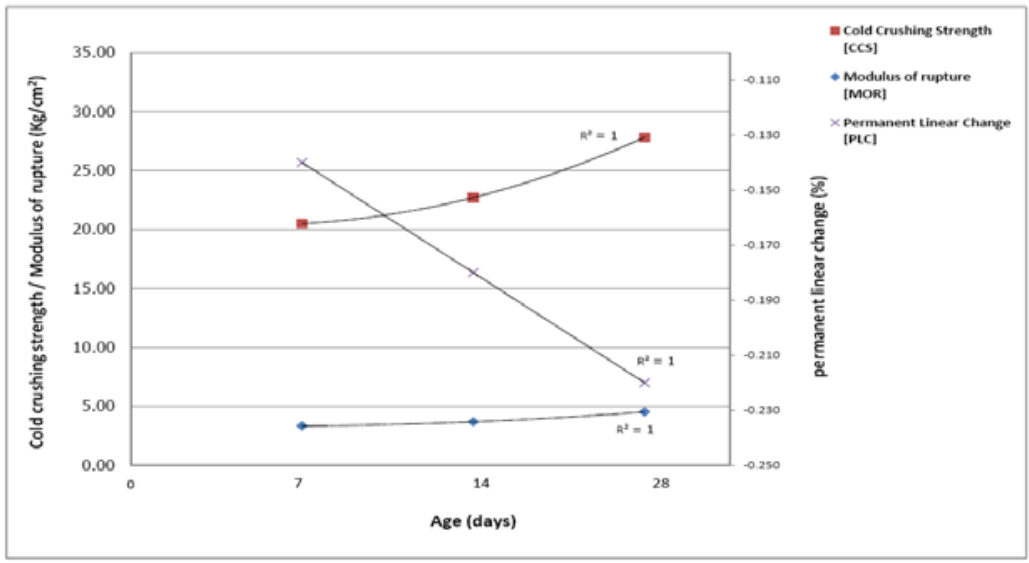

Figure 2. Show the results of CCS, MOR and PLC of SRM 


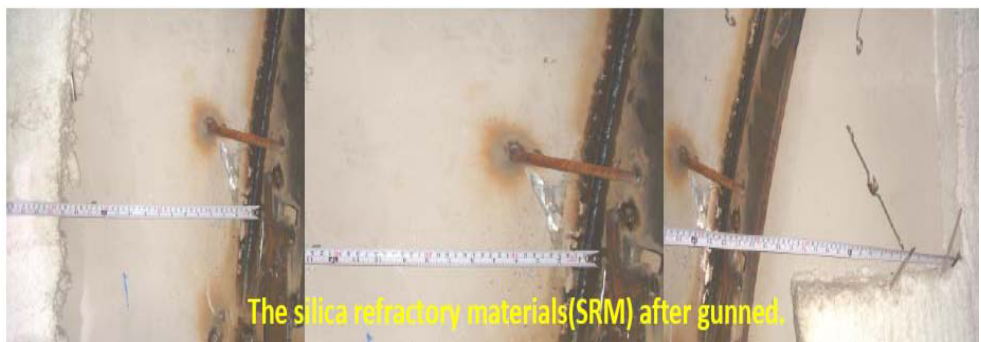

Figure 3. shows the silica refractory materials (Conventional cast grade, CCG) after set in the iron stack of the local agro-industry

On the other hand, the calcium hexaluminate, $\mathrm{CA}_{6}$ exhibites the most good thermal properties of the calcium aluminate system with a melting point above $1850{ }^{\circ} \mathrm{C}$ [14-17]. Also, the Permanent Linear Change (PLC) values show decreasing trend with increasing cured time. The minimum value is $-0.22 \%$ at cured time of 28 days which passes the standard limits [5] which values are between -0.8 to $-0.6 \%$. The unit weight is also observed in this work. Result shows that it increases with cured time. From this study, it can be concluded that the properties of SRM by using Gunned grade, only MOR is lower than the standard. However, considerably from overall properties tested in this work show enough quality to produce as the refractory material, type of the Conventional Cast/Pound $\left(815^{\circ} \mathrm{C}\right)$ as shown in Figure 3.

\section{Conclusions}

This new insulating shows that the strength properties of SRM increases with cured times. Adding silica can increase the durability from the shrinkage and swelling due to changing temperature. Finally, it can conclude that SRM can be used as the refractory material, type of the Conventional Cast/Pound $\left(815^{\circ} \mathrm{C}\right)$ for the local agro- industry using thermal energy. Meanwhile, on the application, insulating product have to meet various requirements of highly efficient thermal insulation properties in order to handle and safe to install, high durability and related costs.

\section{Acknowledgements}

The author would like to express gratitude to researchers, namely Dr. Rattanakorn Rawangkul, STRR Engineering CO.,LTD, Thailand, Assoc. Prof. Dr. Wanchai Yodsudjai, Head of Department of Civil Engineering, Kasetsart University, Assoc. Prof. Dr.Trakool Aramraks Department of Civil Engineering, Kasetsart University, Thailand for their invaluable help and constant encouragement throughout this research. Sincere thanks to the Department of Civil Technology and Architecture for instrument test supporting and Muban Chombueng Rajabhat University, MCRU for partial financial support.

\section{References}

1. F. Valenza, R. Botter, P. Cirillo, F. Barberis, M. di Foggia and D. Sottle, Ceramic International, 36, 459(2010).

2. Salah A., Abo-El-Enein, Morsy M., Abou-Sekkina., Nagy M. Khalil and Osama A. Shalma, Ceramic International, 36, 1711(2010).

3. W. Namboonruang, R. Rawangkul, W. Yodsudjai, Applied Mechanics and Materials, 
117-119,1352 (2012).

4. American Standard Testing and Materials(ASTM) Standard C113-02 Standard Test Methods for Reheat Change of Refractory Brick, ASTM, West Conshohocken, USA, (2008).

5. American Standard Testing and Materials(ASTM) Standard C133-97, Standard Test Methods for Cold Crushing Strength and Modulus of Rupture of Refractories, ASTM, West Conshohocken, USA, (2008).

6. American Standard Testing and Materials(ASTM) Standard C134-95, Standard Test Methods for Size, Dimensional Measurements, and Bulk Density of Refractory Brick and Insulating Firebrick, ASTM, West Conshohocken, USA, (2010).

7. W. Namboonruang, R. Rawangkul, W. Yodsudjai and J. Khedari, Advanced Materials Research, 261-263, 469 (2011).

8. Tessier-Doyen, N., Glandus, J. C. and Huger, M., J. Eur. Ceram. Soc., 26, 289 (2006).

9. Meschke, G., Lackner, R. and Mangan, H. A., Int. J. Numer. Meth. Eng., 42, 703 (1998).

10. Boussuge, M., Key Engine Mater., 264-268(III), 1755 (2004).

11. Ghassemi-Kakroudi, M., Yeugo-Fogaing, Y., Huger, M., Chotard, T. and Gault, C., J. Eur. Ceram. Soc., 28(13), 2471 (2008).

12. Ghassemi-Kakroudi, M., Yeugo-Fogaing, Y., Huger, M., Chotard, T. andGault, C., Thermal history and mechanical properties of alumina castables. Proceedings of 10th International Conference and Exhibition of the European Ceramic Society, 1909 (2007).

13. Ghassemi-Kakroudi M., Huger M., Chotard T. and Gault C., Thermomechanical behaviour of andalusite based refractory castables, Proceedings of the Unified International Technical Conference on Refractories,UNITECR'07, (2007) September, 18-21, Dresde, Germany.

14. Criado E. and de Aza, S., Calcium Hexaluminate as Refractory Materials, Proceedings UNITERCR 91, German Refractories Association, Bonn, 566-574 (1992).

15. Alumina Chemical, Science and Technology handbook. Edited by L.D. Hart.Ceram.Soc., Westerville, Ohio,171-183 (1990)

16. An L., Chan H.M and Soni K.K., Control of Calcium Hexaluminate grain morphology in in-situ toughened ceramic composites.

17. Nakaoka T., Kanzaki S. and Yamaoka Y., Mechanical properties of hot-pressed calcium hexaluminate ceramics, Mat.Sci.Lett, 9, 219-221(1990). 